\title{
DIGITAL LEARNING OF PRE-SERVICE TEACHERS DURING COVID-19 OUTBREAK
}

\author{
Prasart NUANGCHALERM*, Mahasarakham University, Thailand \\ Veena PRACHAGOOL, Mahasarakham University, Thailand \\ Jiř́ DOSTÁL, Univerzita Palackého v Olomouci, Česká republika
}

Přijato: 10. 11. 2020 / Akceptováno: 20. 12. 2020

Typ článku: Teoretická studie

DOI: $10.5507 /$ jtie.2020.007

Abstract: As we known, the Corona Virus Disease 2019 or COVID-19 outbreak is now spreading around the world. It spreads widely and quickly by our social activities. It can be panic to all people who following news from variety of patterns in social medias and online postings. So, it affects continuously a huge threat to the daily life, health care, social activities, and educational management. However, education in this era is supported by multi-medias and tools for learning management. Digital learning is employed to plays it important role in the situation of COVID-19 outbreak. This study employed survey method to investigate readiness on digital learning of science teacher students. Online questionnaire conducted with 36 junior and 38 senior science teacher students. The readiness on digital learning collected, analysed, and reported in terms of mean, standard deviation, and One Way ANOVA. The results found that senior science teachers have more readiness on digital learning than junior science teacher students. The components of digital learning are mostly readiness is at high level, while the creativity and innovation for digital learning is at medium level. The components of digital learning is tested and showed that it is significantly differences at 05 levels of statistics.

Key words: digital learning, readiness, social distancing, teacher education 


\section{DIGITÁLNÍ VÝUKA STUDENTU゚ UČITELSTVÍ BĚHEM PANDEMIE ONEMOCNĚNÍ COVID-19}

Abstrakt: Je známým faktem, že onemocnění způsobené koronavirem nebo jinak řečeno onemocnění COVID-19 se i nadále širíi celým světem, a to prostřednictvím našich společenských aktivit. U osob, které sleduji zpravodajství zejména prostřednictvím sociálních médií a on-line statutů, může vyvolávat pocity paniky. Pandemie stále predstavuje obrovskou hrozbu pro náš každodenni život, naši zdravotni péči, společenské aktivity i pro rízení vzdělávacího procesu. Vzdělávání nicméně v tomto ohledu disponuje multimédii a dalšimi nástroji, které ř́zení výuky pomáhají. V situaci způsobené pandemii onemocnění COVID-19 hraje důležitou roli "digital learning" neboli učení s digitálními technologiemi. Cílem predložené studie bylo zjistit míru pripravenosti na učení s digitálními technologiemi u učitelů př́rodovědných předmětů. Za tímto účelem byla použita metoda výzkumného šetření, uplatněná prostřednictvím dotazníků vyplněných 36 začinajícimi a 38 zkušenými učiteli. Shromážděné výsledky byly analyzovány a zpracovány ve smyslu středni hodnoty, směrodatné odchylky a jednosměrné analýzy rozptylu. $Z$ výsledků vyplývá, že zkušeni učitelé prírodovědných předmětů vykazuji ve většině př́padı̀ vyšši míru připravenosti na učení s digitálními technologiemi než učitelé začinajicí. Při zkoumáni jednotlivých složek učení s digitálními technologiemi vyšlo najevo, že zatímco míra připravenosti je vysoká, kreativita a inovativnost je $v$ tomto ohledu spíše průměrná. Testováním jednotlivých složek digitálního učení se prokázalo, že na hranici významnosti 0,05 jsou výsledky signifikantní.

Klíčová slova: digitální výuka, připravenost, vzdělávání učitelů

* Corresponding author e-mail: prasart.n@msu.ac.th ORCID ID: https://orcid.org/0000-0002-5361-0377 


\section{Introduction}

The multiple unexplained cases of pneumonia were reported on December, 2019 from Wuhan, Hubei Province, People Republic of China. This disease can infect and transmit from human-to-human by social activities. Later, it was confirmed by the World Health Organization (WHO), named it through the characteristics of source of virus, Corona Virus Disease 2019 or COVID-19. It is reported that disease is highly infectious during the incubation period, and asymptomatic infection. Respiratory droplets, contact and aerosols are significant sources of disease spreading. In addition the rate of spreading is rapidly distributed. That is, why, the COVID-19 can impact to emotional citizens, they are coping with thoughts and social actions to deal with stressful situations (Zhong et.al., 2020).

The regulations of each country towards COVID-19 outbreak may be different. People are panic with rapidly spreading news and influence to life activities, working preferences, and learning behaviors (Wang et.al., 2020; Zhang et.al., 2020). So that, learning environment and teaching strategies are adapted to classroom, adopted online learning and multi-function of learning tools to learners. Ministry of Education and educational institutions announced the way from face-to-face into online classroom. However, the direction of the relationship between teachers and students seem to be rapidly changed. Some students and also teachers are not clear, unfamiliar, and unhappy with the new methods of instruction. The online teaching and learning process are announced through minister, presidents of university, and school administrators in different level of policy.

Social distancing is appeared during COVID-19 outbreak for making everyone far from disease. This concept is also employed to education management, teach from home, work from home, and learn from home are alternative choice to do (Amhag et al., 2019). However, it is fast to teachers and learners in preparation facing with this situation. Readiness in digital learning is a key performance that helps social distancing success and open mind to borderless knowledge-society. To understand and prepare students to face with new methods of instruction, teacher students are key person who is professional teachers for future (Sousa et al., 2019). If they have it and can do many digital abilities such as the ability to search for analytical, critical, creative, and reliable information. The ability of digital learning can make them to innovate and develop the learning innovation, communication capabilities, and coordination by digital course designing (Office of the Higher Education Commission, 2018).

Today, the world society and disease crisis have been changed very much, such as innovation and new technology, platform of learning, tools and methods of instruction, nature of learning, and so on. For such important reasons, teacher students who are important in the development of students in the future require digital performance (Best $\&$ MacGregor, 2017; Kearney \& Maher, 2019). Otherwise, there will be problems in teaching 
arrangements whatever something accidents. This is because why teachers are unable to use technology and cannot provide interesting and effective teaching to students. The impact of online learning may be stressful to them as well as pedagogical content knowledge. Based on this situation, the purpose of this study aimed to explore the current status of readiness of teacher students on digital learning during the COVID-19 outbreak.

\section{Methods}

\section{Participants}

An online survey was conducted through Google forms with junior and senior teacher students who are studying in Mahasarakham University, Thailand. They are students in bachelor of education program in field of general science. A total of 16 questionnaires were sent through online request in directly response. Participants consisted 36 of junior teacher students, 5 males (13.89\%) and 31 females $(86.11 \%)$. Senior teacher students are 38 participants, 11 males (28.95\%) and 27 females (71.05\%) are participated.

Research tools

Participants rated the digital learning competency that they experienced on a Likert 5 -point scale, ranging from 1 (lowest) to 5 (highest). Research tool was adapted from Wisetsat \& Wisetsat (2020) based on the digital learning competency of pre-service teachers, consists of six components: (1) using search engine, (2) creativity and innovation, (3) identity and quality of life, (4) teaching and learning technology, (5) tools and technology, and (6) communication and collaboration.

\section{Data collection}

Data were collected by inviting junior and senior science teacher students during the March 2020 which COVID-19 outbreak. University launched alternative patterns to teachers and students to change methods and process to classroom in short time. By announcement of Ministry of Higher Education, Science, Research and Innovation towards COVID-19 outbreak, participants are requested to response their questionnaire through online survey. Data were completed the questionnaire, recheck the completion of form. Then, the data were obtained and recheck the completeness.

\section{Data analysis}

Data were analyzed by descriptive statistics, mean and standard deviation. The level of readiness of science teacher students on digital learning can be calculated and interpreted by indicating into 5 levels of mean for interpreting: highest (4.51-5.00), high (3.51-4.50), medium (2.51-3.50), low (1.51-2.50), and lowest (1.00-1.50). Also, One-way ANOVA is used for testing mean differences between year of study, components of digital learning, and post hoc test is employed for analyzing, LSD is used for correction alpha for pair-wise or simple comparison of means.

\section{Results}

The readiness of science teacher students to face with digital learning through various kinds of methods and processes showed that they are mostly prepared themselves is at high 
level. While their creativity and innovation for digital learning is at medium level (Table 1). However, the information showed that 5 components of readiness are at high level. Using search engine explored that they can seek useful information by employing the various academic search premier tools. But, they seem to assess the reliability of an online data source much more than they do, and can safely access and manage data on the internet. Even though, creativity and innovation seems to be different between years of study. They can produce digital media and present their work through different platforms, and can create innovative teaching materials using digital tools to design tasks. Senior students had high level of readiness in the practice to interact, react and exchange online learning. But, junior students can showed that readiness in medium level.

\begin{tabular}{lcccccc}
\hline & \multicolumn{3}{c}{ Junior students } & \multicolumn{3}{c}{ Senior students } \\
\multicolumn{1}{c}{ Component } & Mean & SD & $\begin{array}{c}\text { Level of } \\
\text { readiness }\end{array}$ & Mean & SD & $\begin{array}{l}\text { Level of } \\
\text { readines }\end{array}$ \\
& & & & & & \\
\hline $\begin{array}{l}\text { Using search engine } \\
\begin{array}{l}\text { Creativity and } \\
\text { innovation }\end{array}\end{array}$ & 3.68 & 0.68 & High & 4.07 & 0.76 & High \\
$\begin{array}{l}\text { Identity and quality of } \\
\text { life }\end{array}$ & 3.81 & 0.86 & Medium & 3.50 & 0.96 & Medium \\
$\begin{array}{l}\text { Teaching and learning } \\
\text { technology }\end{array}$ & 3.69 & 0.76 & High & 3.77 & 0.98 & High \\
$\begin{array}{l}\text { Tools and technology } \\
\text { Communication and }\end{array}$ & 3.78 & 0.66 & High & 3.72 & 0.86 & High \\
collaboration & 3.63 & 0.92 & High & 3.80 & 0.84 & High \\
\hline
\end{tabular}

Table 1 level of readiness on digital learning of science teacher students

Identity and quality of life explored science teacher students can set information security as required by private group or public, prevent data loss, and be careful to provide information from other people, as well as interact with other people online. Teaching and learning technology can explain that they can use the appropriate technology and a variety of learning; can choose to use and install the Learning support program; and can use technology to design and present learning. They can use tools and technology supporting instruction that they can use digital technologies that suit the course of teaching, can continuously monitor the progress of digital technology, and can learn digital technology that is suitable for use.

Communication and collaboration found that they can participate in learning management through a variety of online coordination and can choose to use the right online program to contact coordination, such as Email Line and Facebook. The small point of 
view found that senior students had high level of readiness in the practice that they can use an online or video-conference meeting. But, junior students can showed that readiness in medium level.

Indeed, to understand with information that reported, senior students have mean score higher than junior students. The One-way ANOVA is employed to compare year of study and components (Table 2 and 3). It found that senior and junior science teacher students had different level of readiness to digital learning. It seems that senior science teacher students tend to be level of readiness higher than those junior science teacher students at .05 levels of statistics.

\begin{tabular}{|c|c|c|c|c|c|}
\hline & Sum of & & Mean & & \\
\hline & Squares & $\mathrm{df}$ & Square & $\mathrm{F}$ & Sig. \\
\hline $\begin{array}{l}\text { Between } \\
\text { Groups }\end{array}$ & 4.808 & 1 & 4.808 & 6.701 & .010 \\
\hline Within Groups & 954.414 & 1330 & .718 & & \\
\hline Total & 959.222 & 1331 & & & \\
\hline \multicolumn{6}{|c|}{ Table 2: Comparing mean differences between years of study } \\
\hline & $\begin{array}{c}\text { Sum of } \\
\text { Squares }\end{array}$ & $\mathrm{df}$ & $\begin{array}{l}\text { Mean } \\
\text { Square }\end{array}$ & $\mathrm{F}$ & Sig. \\
\hline $\begin{array}{l}\text { Between } \\
\text { Groups }\end{array}$ & 29.799 & 5 & 5.960 & 8.503 & .000 \\
\hline Within Groups & 929.423 & 1326 & .701 & & \\
\hline Total & 959.222 & 1331 & & & \\
\hline
\end{tabular}

Table 3: Comparing mean differences among components of digital learning

As it shown in Table 3, the component of digital learning of science teacher students is significantly differences at .05 levels of statistics. So that, to understanding how components different, Post hoc test is employed for analyzing, LSD is used for correction alpha for pair-wise or simple comparison of means. The readiness among using search engine, creativity and innovation, and communication and collaboration are significantly differences at. 05 level of statistics. Indeed, creativity and innovation is differences to all components at .05 of statistical significance.

\section{Discussion}

The situation of current disease that make stressful to all people, COVID-19 outbreak affects to people in many ways. Education must be change from face-to-face into online learning or make it to be digital learning. In the suddenly announcements by government, teachers and students have to adapt their instructional behaviors. But less report the readiness on digital learning. That's the study found that the readiness of science teacher 
students are mostly prepared themselves to face with digital learning is at high level. It is surprisingly explored about creativity and innovation of science teacher students is at medium level. The previous studies (Akarawang et al., 2015; Wisetsat \& Wisetsat, 2020) reported that teacher students need to enhance their digital learning competency especially creativity to design learning innovations, learning environment which allow them to have opportunities in digital learning. It may be caused the learning environments are not now suitable for teacher students. Some course of learning, teacher is familiar with lecturebased learning, face to face learning, activity-based learning, or traditional learning. But, in the field of teacher education, we cannot deny course that allow them to practice or learn from real situations. Digital learning may be suitable for some course which theoretical based instruction or lectures (Hanson \& Kutorglo, 2019).

Relevantly, teachers in schools require training information technology skills, practical skills toward ICT because the current situation cannot support them to have adequately knowledge and facilities to employ media technology and online learning for instructional design (Akarawang et al., 2015). Even though science teacher students have high readiness to making digital learning instruction, but they have readiness about creativity and innovation in medium level. So, that is, they need to fulfill abilities for creating and innovating instructional practices as professional standards required (Prachagool et al., 2016; Wisetsat \& Nuangchalerm, 2019). They need to prepare themselves to produce digital media for incoming year and school practicum. Indeed, they are familiar with a variety of digital platforms making valuable practical skills in fruitfulness. The entire experiences help them to have a readiness for practicing, interacting, reacting, and exchanging ideas to create online learning.

Science teacher students can communicate and collaborate others in learning management through a variety of online coordination because they are new Gen teachers, familiar with digital platforms, eager to learn new technology (Dostál et.al., 2017a; Dostál et.al., 2017b; Nuangchalerm, 2017). They may be familiar with presentation in front of the classroom with peers, teach students by face-to-face as well. The finding from this study showed that they are not familiar with video-conference meeting. Due to online conference is good for ready school where internet and technology supports are well prepared. The readiness of science teacher students among using search engine, creativity and innovation, and communication and collaboration are need to be promoted. Especially, the empirical evidence show that they have creativity and innovation in different to other components. They would be digital teachers who are facing new learning environments not only COVID-19 outbreak, but also uncertainty in the changing world is now challenging (Emmanuel \& Jamilu, 2016; Faustmann et.al., 2019; Xu et.al., 2019). 


\section{Conclusion}

COVID-19 is a pressure source with learning environments which teachers and students have to learn in adaptable, accessible during COVID-19 pandemic. Digital learning is welcome to make students far from it spreading. The study explored the readiness of students among using search engine, creativity and innovation, and communication and collaboration are needed for prepare them to face with digital learning. However, not only science teacher students have to prepare their readiness, but also other social sectors need to be learned and implied to way of life.

\section{Bibliography}

Akarawang, C., Kidrakran, P., \& Nuangchalerm, P. (2015). Enhancing ICT competency for teachers in the Thailand basic education system. International Education Studies, $8(6)$, 1-8. doi:10.5539/ies.v8n6p1

Amhag, L., Hellström, L., \& Stigmar, M. (2019). Teacher educators' use of digital tools and needs for digital competence in higher education. Journal of Digital Learning in Teacher Education, 35(4), 203-220. doi: 10.1080/21532974.2019.1646169

Best, M., \& MacGregor, D. (2017). Transitioning design and technology education from physical classrooms to virtual spaces: implications for pre-service teacher education. International Journal of Technology and Design Education, 27(2), 201-213. doi:10.1007/s10798-015-9350-z

Dostál, J., Wang, X., \& Nuangchalerm, P. (2017a). Experiments in education supported by computer use: Teachers' attitudes towards computers. Proceeding of the $9^{\text {th }}$ International Conference on Computer Supported Education (CSEDU 2017). Pp. 248-254. doi: 10.5220/0006321302480254

Dostál, J., Wang, X, A. Steingartner, W. \& Nuangchalerm, P. (2017b). Digital intelligence-New concept in context of future school of education. Proceedings of ICERI2017 Conference. Pp. 3706 - 3712.

Emmanuel, R., \& Jamilu, H. Y. (2016). Occupational stress and management strategies among technology education teachers in higher institutions. Journal of Education, Society and Behavioural Science, 1-12. doi: 10.9734/BJESBS/2016/25361

Faustmann, G., Lemke, C., Kirchner, K., \& Monett, D. (2019). Which factors make digital learning platforms successful?. Proceeding of the $13^{\text {th }}$ Annual International Technology, Education and Development Conference. Pp. 6777-6786). doi: 10.21125/inted.2019.1651 Hanson, R., \& Kutorglo, E. (2019). The use of a digital learning system for developing pedagogical skills: Ideas for research-based practice. Journal of Information Technologies and Lifelong Learning, 2(2), 88-96.

Kearney, M., \& Maher, D. (2019). Mobile learning in pre-service teacher education: Examining the use of professional learning networks. Australasian Journal of Educational Technology, 35(1), 135-148. doi: 10.14742/ajet.4073 
Nuangchalerm, P. (2017). Preservice teachers' twenty first century learning skills: Three different majors of study. International Journal of Advanced and Applied Sciences, 4(7),124-128. doi: 10.21833/ijaas.2017.07.018

Office of the Higher Education Commission. (2018). Announcement of guidelines for compliance with the national higher education qualifications framework for digital competency for undergraduate qualifications. Bangkok: OHEC.

Prachagool, V., Nuangchalerm, P., Subramaniam, G. \& Dostál, J. (2016). Pedagogical decision making through the lens of teacher preparation program. Journal for the Education of Gifted Young Scientists, 4(1), 41-52. doi: 10.17478/JEGYS.2016116351

Sousa, M. J., Carmo, M., Gonçalves, A. C., Cruz, R., \& Martins, J. M. (2019). Creating knowledge and entrepreneurial capacity for HE students with digital education methodologies: Differences in the perceptions of students and entrepreneurs. Journal of Business Research, 94, 227-240. doi: 10.1016/j.jbusres.2018.02.005

Wang, C., Cheng, Z., Yue, X. G., \& McAleer, M. (2020). Risk management of COVID19 by universities in China. Journal of Risk and Financial Management. 13(56), 1-6. doi: $10.3390 / \mathrm{jrfm} 13020036$

Wisetsat, C., \& Nuangchalerm, P. (2019). Enhancing innovative thinking of Thai preservice teachers through multi-educational innovations. Journal for the Education of Gifted Young Scientists, 7(3), 409-419. doi: 10.17478/jegys.570748

Wisetsat, C., \& Wisetsat, W. (2020). A need study to enhance pre-service teachers' digital competencies. Journal of Yala Rajabhat University, 15(1), 105-116.

Xu, S., Yang, H. H., MacLeod, J., \& Zhu, S. (2019). Interpersonal communication competence and digital citizenship among pre-service teachers in China's teacher preparation programs. Journal of Moral Education,48(2), 179-198. doi: 10.1080/03057240.2018.1458 605

Zhang, W., Wang, Y., Yang, L., \& Wang, C. (2020). Suspending classes without stopping learning: China's education emergency management policy in the COVID-19 outbreak. Journal of Risk and Financial Management, 13(55), 1-6. doi: 10.3390/ jrfm13030055 Zhong, B. L., Luo, W., Li, H. M., Zhang, Q. Q., Liu, X. G., Li, W. T., \& Li, Y. (2020). Knowledge, attitudes, and practices towards COVID-19 among Chinese residents during the rapid rise period of the COVID-19 outbreak: a quick online cross-sectional survey. International Journal of Biological Sciences, 16(10), 1745-1752. doi: 10.7150/ ijbs. 4522 